\title{
Natural Ingredients in Cosmetics from Malaysian Plants: A Review
}

(Bahan Semula jadi dalam Kosmetik daripada Tumbuhan di Malaysia: Suatu Sorotan)

\author{
HASMIDA MOHD-NASIR \& SITI HAMIDAH MOHD-SETAPAR*
}

\begin{abstract}
Consumer consciousness on the concept of natural-based ingredients triggers the natural cosmetics market to grow. The active compounds in natural ingredients offer valuable bioactivities such as antioxidant, photoprotection, anti-aging and anti-inflammatory actions that useful for skincare, hair care and dental care. This review presents an overview on natural ingredient, especially plant-derived, used in cosmetic products and the examples of Malaysian plants used for cosmetic purposes.
\end{abstract}

Keywords: Active compounds; bioactivities; cosmetic; natural ingredient; plant-derived

\section{ABSTRAK}

Kesedaran pengguna terhadap konsep bahan berasaskan semula jadi mencetuskan perkembangan pasaran kosmetik semula jadi. Sebatian aktif dalam bahan-bahan semula jadi menawarkan bioaktiviti yang berharga seperti antioksidan, perlindungan sinaran, anti-penuaan dan anti-radang yang berguna untuk penjagaan kulit, penjagaan rambut serta penjagaan pergigian. Kertas ini membentangkan gambaran keseluruhan berkenaan bahan-bahan semula jadi, terutamanya daripada tumbuhan, yang digunakan dalam produk kosmetik dan contoh tumbuhan di Malaysia yang digunakan untuk tujuan kosmetik.

Kata kunci: Bahan semula jadi; bioaktiviti; janaan tumbuhan; kosmetik; sebatian aktif

\section{INTRODUCTION}

The word cosmetic is always link to beauty. Cosmetic defines by Food, Drug and Cosmetic Act as 'articles intended to be rubbed, poured, sprinkled, or sprayed on, introduced into, or otherwise applied to the human body for cleansing, beautifying, promoting attractiveness, or altering the appearance'. By this definition, Thornfeldt (2005) listed several products that can be denoted as cosmetic which are shampoo, facial makeup, skin moisturizer, toothpaste, hair colour, deodorant and any component used in cosmetic product. In short, skincare, hair care, dental care, nail care and fragrance can be categorized as cosmetic products. Cosmetics are often used to take care of body parts, but its alone does not provide beneficial effect to the users. The association of active ingredients into the cosmetic products are essential to enhance the healthiness of the skin besides other activities as well, anti-aging, moisturizing and acne treatment. The cosmetic products with active ingredients having medicinal or drug-like benefits are called cosmeceutical (Kadam Vaishali et al. 2013). Cosmeceuticals reportedly are the fast-growing segment in personal care industry (FDA 2002).

Current demand of going green triggers the growth of natural cosmetic products in the market. The manufacturers often labelled their products associates with plant-based or organic ingredients as 'chemical-free' emphasizing lack or no potential harmful ingredients such as paraben and silicone in their products (Belova \& Eilks 2015). The term 'natural' for labelling especially food products is permitted by U.S. Department of Agriculture if there are no artificial flavour, colour, chemical preservative or any artificial or synthetic ingredient (Peng et al. 2014). According to Corley (2007) and Matthews (2007), the Natural Products Association (NPA) recognizes products as natural if it contains $95 \%$ or more of ingredients from natural sources. However, no international definitions of natural cosmetic have been specified. Nevertheless, natural cosmetic is a general term which applied to all preparation for external conditioning and beautifying the body from ingredients produced by or found in nature (Ammar et al. 2011; Dorland 2000).

Active ingredients from natural sources (plants, animals, microorganisms) have been traditionally used for centuries in topical creams and lotions (Fowler Jr. et al. 2010). The concern of consumer and huge potential of natural ingredients contributes to prevalent utilization of them in various industries (e.g. pharmaceutical, nutraceutical \& cosmeceutical). Natural sources may contain polyphenols, terpenes, fatty acids and vitamin. that promote several bioactivities and can be associated in cosmetic products. For example, natural skin care formulations exhibit antioxidant, hyperpigmentation inhibition and antimicrobial properties are beneficial to improve skin tone, texture and appearance (Emerald et al. 2016). 
Malaysia is a country rich in plant biodiversity, which traditionally used for decades in wide range of purposes, be it for medical, beauty or cooking. This review will focused on plant-based constituents and summarized the history of natural cosmetic, market demand, some natural ingredients used in cosmetics, examples of Malaysia's plants with their biological effects and difficulties faced in order to turn the ingredients into products.

\section{HISTORY}

The history of cosmetic usage has started since prehistoric time as illustrated in Figure 1. In the past, Aburjai and Natsheh (2003) stated that people used natural ingredients in cosmetic with plant as a main source of it. However, with the development of technology and civilization, the methods to synthesize substances with similar values were discovered. With that, the dependency on natural resources decreased until 20th century where the demand for green and safe cosmetics come in light due to consumer awareness of disadvantages offers by artificial or synthetic products.

\section{MARKET POTENTIAL}

The demand in personal care market with active ingredient is expanding driven by two major factors (Owh et al. 2016). First is consumer awareness on environmental issue and preference of healthy lifestyle. According to
Kumar et al. (2016), natural cosmetic are in trend due to several reasons which are; they are natural and free from harmful chemical which minimizes the chance of adverse health problems, safe to use, compatible with all skin types, no side effect and nutrients provided by natural sources. Technological advancement is another driver for market growth where the manufacturers are competitively researching on active constituents to meet customer expectation. Costa (2015) reported that the number of products in skincare sector with natural ingredients as main substances has increased from 900 in 2005 to approximately 6000 in 2012 . Generally, Grand View Research, Inc. (2016) forecasted that the global organic personal care market will reach approximately USD 25.11 billion by 2025 . At present, more than $30 \%$ of the global share in 2015 was leading by U.S. organic cosmetic ingredient market, based on report by Global Market Insights Inc. (2016). The increasing of living standard and demand for natural cosmetics in Asia Pacific countries is expected to lead a remarkable growth in revenue for this industry in the near future.

\section{NATURAL INGREDIENTS IN COSMETICS}

The efficiency of active ingredients to be used in cosmetics attributes to bioactivities present in the compounds. Several properties have been reported to give advantages for skin, hair and dental, for instance antioxidant, anti-inflammatory, photoprotective, anti-aging and wound healing. This

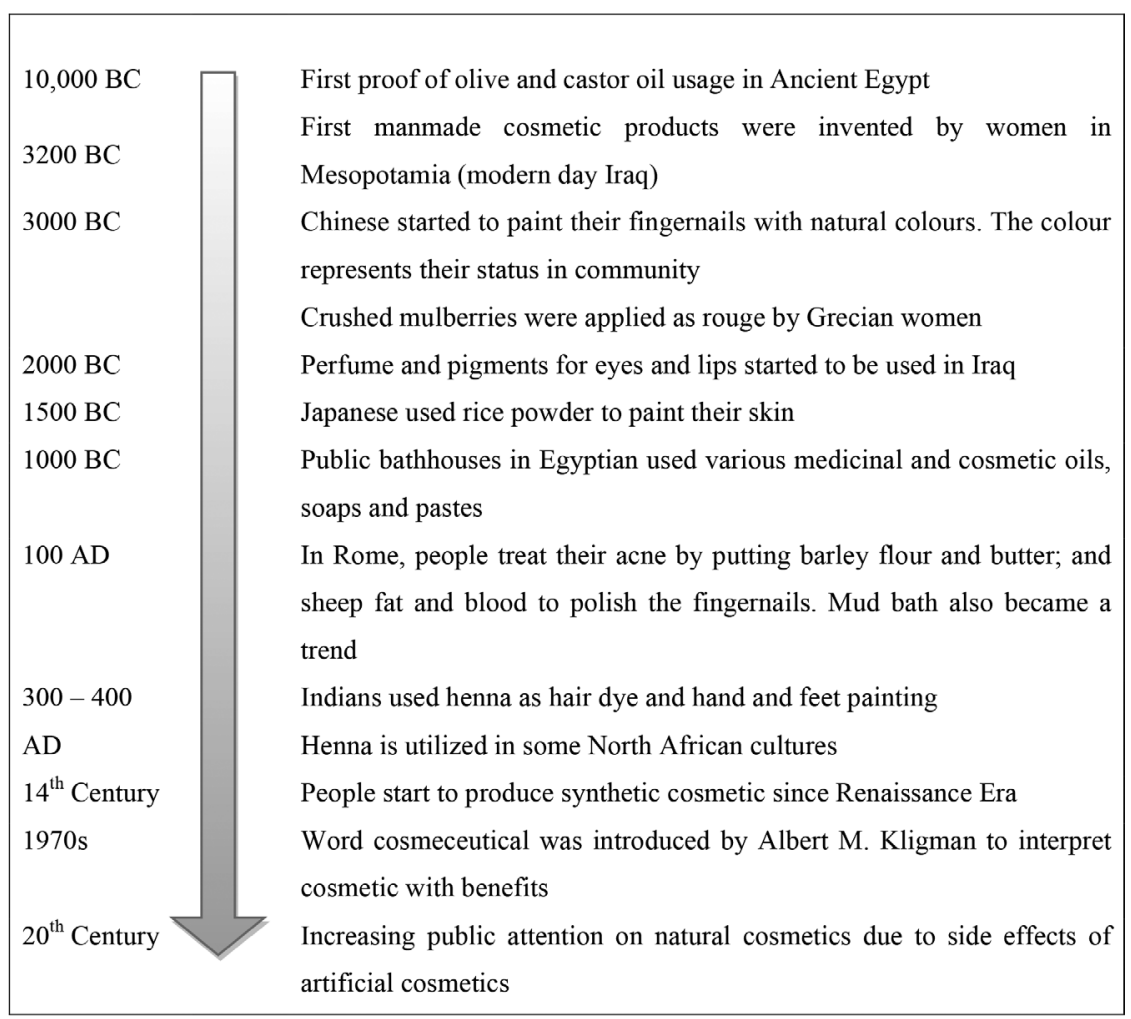

Sources: Kadam Vaishali et al. (2013); Personal Care Products Council (2016); Lambert (2017); History of Cosmetics (2017) FIGURE 1. Historical background of natural cosmetics 
section will briefly summarize the role and potential of major active compounds in cosmetic formulation.

\section{FATTY ACIDS}

Fatty acids used in cosmetics or personal care products are obtained from seeds or nuts oil. They are divided to two categories which are saturated (e.g. lauric, palmitic, stearic) and unsaturated (e.g. linoleic, linolenic, oleic) fatty acids. Linoleic acid is the most common fatty acid applied in cosmetic as it moisturizes the skin and for acne treatment. The anti-inflammatory action proved that the application of $\gamma$-linoleic acid or omega-3 rich oil on 45 participants decreased moderate acne significantly (Jung et al. 2014). On another note, fatty acids are reported to increase absorbing effect of skin. A study was conducted by Kim et al. (2008) to investigate the skin permeation ability of different fatty acids on diclofenac. It was found that fatty acids with short carbon-chain (C-12 to 16), highlighting palmitic acid, were effective in enhancing skin permeation compared to long carbon-chain fatty acids. The role of fatty acids especially omega-3 (linolenic acid) and omega-6 (linoleic acid) are extended to hair cosmetic. The experiment was done by 6 -months oral hair supplement of omega- 3 and 6 associates with other antioxidants on 120 female respondents (Le Floc'h et al. 2015). The observation towards hair density, telogen percentage and proportion of miniaturized anagen hair showed positive results and it was concluded that fatty acids can effectively prevent hair loss. Lee et al. (2014) reported the potential use of omega- 3 from rubber seeds as potential ingredient in lip balm due to its moisturizing and smoothness properties. Ionescu (Bordei) et al. (2015) also suggested the importance of antioxidant activity of fatty acids in vegetable oils for cosmetic uses.

\section{POLYPHENOLS}

Polyphenols are secondary plant metabolites with large group of substances based on the number and position of hydroxyl groups attached to benzene rings (Vermerries \& Nicholson 2006). The substances lies in this category are phenolic acids, flavonoids (e.g. falvonols, aproanthocyanidins), tannins, coumarins and stilbenes. The scientific researches of these compounds have been extensively done especially on flavonoids group. The antioxidant, antimicrobial and anti-inflammatory actions present are beneficial in skin related cosmetic products (Zillich et al. 2015). A clinical study was conducted by Chuarienthong et al. (2010) where the efficacy of antiwrinkle formulations containing flavonoids from gingko and mixture of tea and rooibos was evaluated. Twenty healthy women who meet the requirements were recruited and the observation was done for 28 days. The results suggested that gingko formula was best for anti-wrinkle treatment since it can increase skin moisturization and smoothness; and reduce skin roughness and wrinkle. The other formulation also showed positive effect in reducing wrinkles of experimental group. Phenolic compounds rich extract of white kwaokrua plant was analyzed for their anticollagenase, anti-elastase and antioxidant properties (Chattuwatthana \& Okello 2015). By investigation using in vitro enzymatic assays, the extract was significantly inhibiting elastase activity and collagenase activity was comparable to those of positive control, epigallocatechin gallate. The potential of white kwaokrua extract in decelerating aging process has been proven through this work. In addition, the study depigmenting effects of catechins are shown to promote melanin synthesis inhibition of B16 melanoma (Sato \& Toriyama 2009). Polyphenols can also act as photoprotection (Martorana et al. 2013; Ruszova et al. 2013; Sevin et al. 2007) thus allowing the compounds to incorporate in sunscreen formulation as a prevention against ultraviolet (UV) radiation.

\section{CAROTENOIDS}

The best known antioxidants in carotenoids that always been applied in various industries are B-carotene, lycopene, lutein, astaxanthin and zeaxanthin (Anunciato \& Filho 2011). Carotenoids act as photoprotective against UV radiation due to it oxidative effect (Pandel et al. 2013). Research by Scarmo et al. (2010) highlighted lycopene and $\beta$-carotene function as natural skin photoprotection due to high level of the compound present in human skin of U.S. population compared to lutein and zeaxanthin. Nevertheless, the roles of lutein and zeaxanthin towards photoprotective, skin elasticity and skin lipid peroxidation has been proved by performing a clinical trial (Palombo et al. 2007). The caroteniods were taken orally, topically or in combination by human subjects either individual or both compounds. The highest antioxidant protection was shown by administration of combined oral and topical application for lutein and zeaxanthin. However, the individual compound also indicates significant effect of skin photoaging and skin elasticity. Skin lightening is one of the advantages offer by caroteniods. A pilot study was conducted by Teo et al. (2015) to assess the effectiveness of carotenoids rich dietary supplements as an addition to oral usage of commercial lightening cream for melasma treatment. From 44 patients completing the study, the authors concluded that oral supplements containing carotenoids decrease hyperpigmentation and serve as a potential skin lightening agent to treat skin problem. According to Saba (2016), besides providing glow to skin, the consumption of $\beta$-carotene at adequate level can prevent hair problems such as hair loss and dandruff.

\section{PHYTOSTEROLS}

Phytosterols (plant sterols) are cholesterol-like molecule and can be found in vegetable oils such as avocado, soy bean and pumpkin seeds. They are normal components in human diet. In cosmetic industry, a report prepared by Becker (2013) listed the products used phytosterols as 
one of the ingredients which are 177 leave-on products (lipsticks, deodorants, eye makeup); 215 rinse-off products (hair products, bath soaps, detergents); tanning preparations and up to $0.05 \%$ phytosterol was used in face powders. Quirin (2011) published in Euro Cosmetics magazine that phytosterol possess photoprotective and anti-wrinkle efficacy owing to cell division encouragement ability. Plant sterols are also provides moisture, barrier protection and antioxidant ability which present nutrition for health and skin (Fowler Jr. et al. 2010). Puglia and Bonina (2008) presented a work to evaluate the effect of topical application of soy phytosterols on skin damage and recovery of skin barrier. Two formulations were used; phystosterols + di-n-butyl adipate solution and vehicle only; in order to compare the efficiency of active component with untreated site of skin damage. The finding showed that the formulation containing phytosterols exerts positive results on skin repair and barrier function recovery owing to biological response showed by the compound. Another study by Sun et al. (2014) proved antiaging and anti-oxidative stress of sterol fraction, mainly steroid, obtained from mussel. The data found from the investigation indicate that sterol fraction can prolonged the life expectancy of yeast.

\section{VITAMINS}

Vitamin is an organic compound and vital nutrient for human being. Different types of vitamin have been studied extensively in literature. The antioxidant and anti-aging benefit of vitamin A (retinol) is reported to reduce wrinkles, depigmentation and provide skin smoothness. Forty one healthy women were subjected to clinical evaluation by applying retinol formulation to the full face for 3 months (Kong et al.2015). One of the research aims was to analyse the effect of retinol treatment on facial wrinkle. The study demonstrates that topical application of retinol render anti-aging effect since epidermal thickening was observed. In another study, the role of vitamin $\mathrm{C}$ or ascorbic acid was highlighted. Vitamin $\mathrm{C}$ is the major aqueous-phase antioxidant in human body. Lotions, serums, creams and patches are among the products that used vitamin $\mathrm{C}$ in the formulation. It enhances skin lightening because this compound acts as tyrosinase inhibitor. Choi et al. (2010) indicates the effectiveness of vitamin $\mathrm{C}$ on melanogenesis inhibition; and mushroom tyrosinase inhibition and antioxidation. However, multivitamin supplements were better in inducing hyperpigmentation action due to combined beneficial activities. Ascorbic acid is also potent in skin elasticity enhancement and treatment of skin problems such as acne and rosacea owing to its collagen synthesis and anti-inflammatory properties, respectively (Telang 2013). In addition, Beoy et al. (2010) stressed the important of vitamin E mainly tocotrienol in case of alopecia, atype of hair loss. A group of volunteers consumed the supplement containing tocotrienol for 8 months. The data showed that the number of hairs increased by average of $34.5 \%$ compared to controlled group (placebo). The role of oxidative stress was associated with hair loss treatment in this study.

\section{COSMETICS FROM MALAYSIA'S PLANT SOURCE}

Active ingredients can be obtained from plants as one of the important sources in cosmetic industry. The biological benefits possess by oil or extract of the plants often related to its functions either preventing or treating skin, hair or dental problems. For instance, antioxidants are responsible for oxidative damage prevention by chain-breaking of free radicals. With that, they can inhibit oxidation reaction and act as protectors of other ingredients. Antioxidants were also useful to protect human skin from ultraviolet radiation (Kusumawati \& Indrayanto 2013). According to Soto et al. (2015), the scavenging activities of active compounds towards reactive oxygen species (ROS) make them applicable for anti-aging purposes. Tyrosinase inhibition activity is an essential factor for whitening or antihyperpigmentation agent because this property is able to suppress dermal-melanin production (Uchida et al. 2014). Other than that, antimicrobial activity is reported to be an effective treatment against acne (Shinkafi \& Ndanusa 2013). Table 1 demonstrates several examples of plants native or can be found in Malaysia which can be used in cosmetics based on different categories as well as their therapeutic values and functions.

\section{CHALLENGES}

Incorporating natural ingredients into cosmetics obviously provide good results, especially to consumers. However, there are several points need to be considered by the manufacturers in utilizing natural ingredients. According to Emerald et al. (2016), finding a reliable supplier with good quality of source, established quality assurance procedures and services, clean processing and eliminates cross contamination has become a major challenge in cosmetic and personal care industry. The risk of microorganism contamination also should not be ruled out when dealing with natural products. The absence of official guidelines for safety assessment related to plant-derived ingredients also contributes to the difficulties in cosmetic industry. This is due to the different approach in characterizing the natural ingredients from plants, either by the mixture of components or the specific component content (Antignac et al. 2011; Bialek et al. 2016). In view of the matter, it is recommended to the authorities to prepare a proper measure of different cases for better evaluation of safety.

Kusumawati and Indrayanto (2013) reported that antioxidant activity which often cooperated with natural ingredient is chemically unstable so that maintaining the bioactivities of natural antioxidants such as whitening effect, hydrating and depigmentation is problematic. Hence, a perfect formulation involving concentration of natural ingredients need to give careful consideration and optimized so that the benefits claimed are not detrimental. One of prevention step to overcome instability problem 


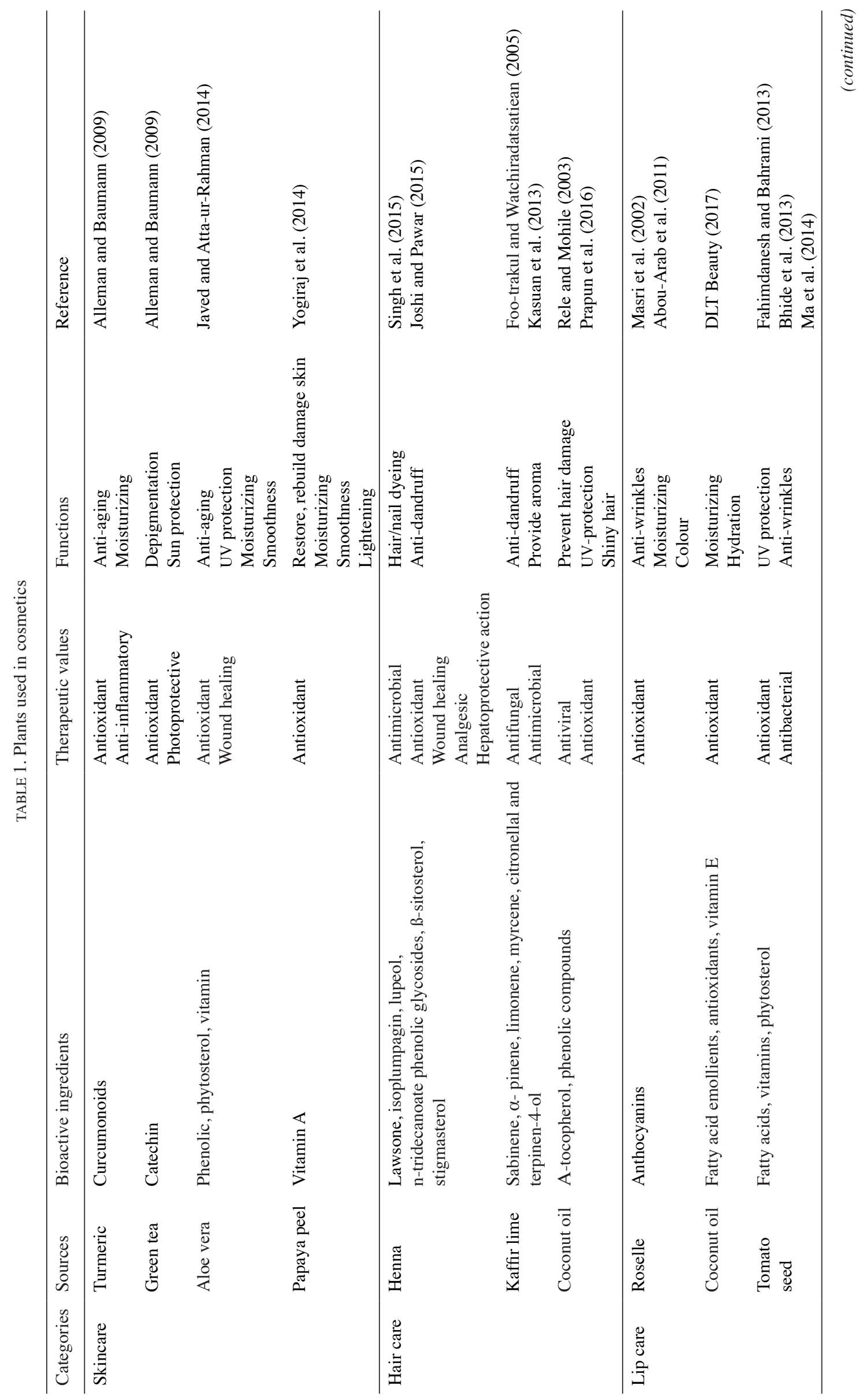




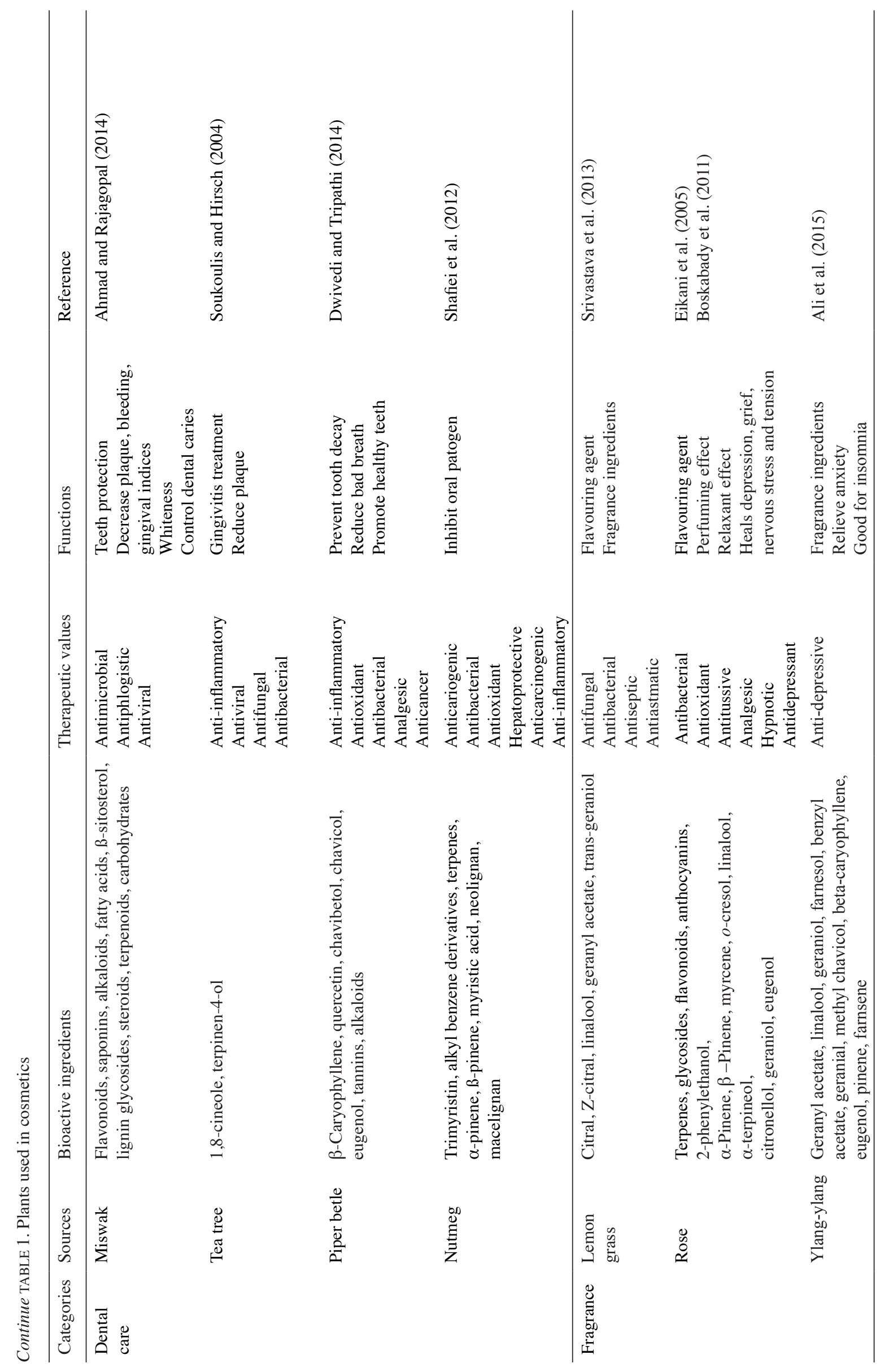


suggested is by employing delivery system technology, for example niosome, nanoparticle emulsion and lipid nanoparticles, as it can improve stability, reduce degradation process and maintain pharmacological values of the compounds or formulation (Aziz et al. 2016).

Natural ingredients especially fragrance are reported to cause allergic effect as well to the consumer whom sensitive to specific compound. Therefore, González-Mũ noz et al. (2014) stressed the important of correctly labelled the cosmetic products to avoid the contact of consumer with potential allergens component. Besides, the cytotoxicity, solubility and unfavourable effect of the raw ingredients or formulation are important measures for utilization and application in commercial products (Hassanien et al. 2014; Kamakshi 2012). Thus, Argyropoulo et al. (2013) mentioned that the clinical trial of the natural ingredients should be accompanied by cell-based assays especially on model organism to access their properties and suitable dosage for topical or oral use so that the cosmetics do not adversely affecting the users.

In order to overcome the challenges and difficulties toward green cosmetic products, all parties involved should take action in conveying information and nutritional values to the market and end users accurately.

\section{CONCLUSION AND FUTURE PROSPECTIVE}

Incorporation of natural ingredients in cosmetics is an alternative to prevent adverse effect from chemical or artificial compounds usage. In addition to advantages offer by natural ingredients, the economic potential of natural cosmetics in beautification for human being is favourable. The exploitation of natural resources is not only beneficial to the manufacturer, but also to the consumer in order to lead healthy life style. Even though numerous scientific studies have been reported on the functions and potential of individual and/or mixture of natural phytochemicals, further investigation is needed including clinical trial and formulation in order to successfully utilize natural ingredients. It is important to establish a joint effort between academician and industrial professionals to ensure smooth development of innovative cosmetic products. As a conclusion, going natural in cosmetic sectors show promising progress worldwide and it is expected to keep expanding to meet growing consumer demand.

\section{ACKNOWLEDGEMENTS}

The authors acknowledge the Ministry of Higher Education (MOHE), Malaysia and Universiti Teknologi Malaysia for the financial support of Research University Flagship, FRGS and OTR grants.

\section{REFERENCES}

Abou-Arab, A.A., Abu-Salem, F.M. \& Abou-Arab, E.A. 2014. Physico-chemical properties of natural pigments (anthocyanin) extracted from Roselle calyces (Hibiscus subdariffa). Journal of American Science 7(7): 445-456.
Aburjai, T. \& Natsheh, F.M. 2003. Plant used in comestics. Phytotherapy Research 17: 987-1000.

Ahmad, H. \& Rajagopal, K. 2014. Salvadora persica L. (Meswak) in dental hygiene. The Saudi Journal for Dental Research 5(2): 130-134.

Alleman, I.B. \& Baumann, L. 2009. Botanicals in skin care products. International Journal of Dermatology 48: 923-934.

Ali, B., Al-Wabel, N.A., Shams, S., Ahamadm, A., Khan, S.A. \& Anwar, F. 2015. Essential oils used in aromatherapy: A systemic review. Asian Pacific Journal of Tropical Biomedicine 5(8): 601-611.

Ammar, N.M., Mohammed, S.H., Doha, A.M., Nabil, E.K., Ahmed, H.A. \& Tom, J.M. 2011. Phytochemical and biological studies of butea frondosa Roxb. leaves growing in Egypt. Medical Journal of Islamic World Academy of Sciences 19(4): 173-180.

Antignac, E., Nohynek, G.J., Re, T., Clouzeau, J. \& Toutain, H. 2011. Safety of botanical ingredients in personal care products/cosmetics. Food and Chemical Toxicology 49: 324-341.

Anunciato, T.P. \& Filho, P.A.d.R. 2011. Carotenoids and polyphenols in nutricosmetics, nutraceuticals, and cosmeceuticals. Journal of Cosmetic Dermatology 11: 51-54

Argyropoulou,A., Aligiannis, N., Trougakos, I.P. \& Skaltsounis, A.L. 2013. Natural compounds with anti-ageing activity. Natural Product Reports 30: 1412-1437.

Aziz, Z.A.A., Ali, S.A.M., Ahmad, A. \& Mohd-Setapar, S.H. 2016. Application of herbal extract and its medicinal value. Der Pharmacia Lettre 8(9): 161-167.

Becker, L.C. 2013. Safety Assessment of Phytosterols as Used in Cosmetics. Washington: Cosmetic Ingredient Review.

Belova, N. \& Eilks, I. 2015. Learning with and about advertising in chemistry education with a lesson plan on natural cosmetics-A case study. Chemistry Education Research and Practice 16: 578-588.

Beoy, L.A., Woei, W.J. \& Hay, Y.K. 2010. Effects of tocotrienol supplementation on hair growth in human volunteers. Tropical Life Sciences Research 21(2): 91-99.

Bhide, D.R., Karadbhajne, V.Y., Khotpal, R.R. \& Kulkarni, A.S. 2013. Fatty acids distribution in lipids of orange and tomato seeds of Vidarbha region (Maharashtra). Journal of Chemical and Pharmaceutical Research 5(4): 13-15.

Bialek, A., Bialek, M., Jelinska, M. \& Tokarz, A. 2016. Fatty acid profile of new promising unconventional plant oils for cosmetic use. International Journal of Cosmetic Science 38: 382-388.

Boskabady, M.H., Shafei, M.N., Saberi, Z. \& Amini, S. 2011. Pharmacological effects of Rosa damascena. Iranian Journal of Basic Medical Sciences 14(4): 295-307.

Chattuwatthana, T. \& Okello, E. 2015. Anti-collagenase, antielastase and antioxidant activities of Pueraria candollei var. mirifica root extract and Coccinia grandis fruit juice extract: An in vitro study. European Journal of Medicinal Plants 5(4): 318-327.

Choi, Y.K., Rho, Y.K., Yoo, K.H., Lim, Y.Y., Li, K., Kim, B.J., Seo, S.J., Kim, M.N., Hong, C.K. \& Kim, D.S. 2010. Effects of vitamin $\mathrm{C}$ vs. multivitamin on melanogenesis: Comparative study in vitro and in vivo. International Journal of Dermatology 49: 218-226.

Chuarienthong, P., Lourith, N. \& Leelapornpisid, P. 2010. Clinical efficacy comparison of anti-wrinkle cosmetics containing herbal flavonoids. International Journal of Cosmetic Science 32: 99-106. 
Corley, J.W. 2007. Natural and organic: The emerging revolution. In Natural and Organics in Cosmetics: From $R$ and $D$ to the Marketplace, edited by Lawrence, B.M. USA: Allured Publishing Corporation. pp. 55-66.

Costa, I.M. 2015. Phytocosmetics - Where nature meets wellbeing. International Journal of Phytocosmetics and Natural Ingredients 2(1): 1-3.

DLT Beauty. 2017. The Best Essential Oils for Dry Lips. http:// darklipstips.com/essential-oils-for-dry-lips.html. Accessed on 11 July 2017.

Dorland, W.A.N. 2000. Dorland's Illustrated Medical Dictionary (29th ed). Philadelphia, PA, USA: W.B. Saunders Company.

Dwivedi, V. \& Tripathi, S. 2014. Review study on potential activity of Piper betle. Journal of Pharmacognosy and Phytochemistry 3(4): 93-98.

Eikani, M.H., Golmohammad, F., Rowshanzamir, S. \& Mirza, M. 2005. Recovery of water-soluble constituents of rose oil using simultaneous distillation-extraction. Flavour and Fragrance Journal 20: 555-558.

Emerald, M., Emerald, A., Emerald, L. \& Kumar, V. 2016. Perspective of natural products in skincare. Pharmacy \& Pharmacology International Journal 4(3): 72.

Fahimdanesh, M. \& Bahrami, M.E. 2013. Evaluation of physicochemical properties of Iranian tomato seed oil. Journal of Nutrition \& Food Sciences 3(3): 1-4.

FDA/CFSAN. 2002. Is it a Cosmetic, a Drug or Both (or is it Soap?). US: Food and Drug Administration.

Foo-trakul, P. \& Watchiradatsatiean, C. 2005. Development of anti-dandruff shampoo from kaffir lime which is the byproduct of food industry. Kasetsart Journal (Natural Science) 39: 725-729.

Fowler Jr., J.F., Woolery-Lloyd, H., Waldorf, H. \& Saini, R. 2010. Innovations in natural ingredients and their use in skin care. Journal of Drugs and Dermatology 9(6): 72-81.

Global Market Insights Inc. 2016. Organic Cosmetic Ingredients Market Size, Industry Analysis Report, Regional Outlook (U.S., Germany, UK, Italy, Russia, China, India, Japan, South Korea, Brazil, Mexico, Saudi Arabia, UAE, South Africa), Application Development Potential, Price Trend, Competitive Market Share \& Forecast, 2016 - 2023. https:// www.gminsights.com/industry-analysis/organic-cosmeticingredients-market. Accessed on 8 March 2017.

González-Mu noz, P., Conde-Salazar, L. \& Va nó-Galván, S. 2014. Allergic contact dermatitis caused by cosmetic products. Actas Dermosifiliograficas 105(9): 822-832.

Grand View Research, Inc. 2016. Organic Personal Care Market Size to Reach USD25.1 Billion by 2025. http:// www.grandviewresearch.com/press-release/global-organicpersonal-care-market. Accessed on 7 March 2017.

Hassanien, M.M.M., Abdel-Razek, A.G., Rudzińska, M., Siger, A., Ratusz, K. \& Przybylski, R. 2014. Phytochemical contents and oxidative stability of oils from non-traditional sources. European Journal of Lipid Science and Technology 116: 1563-1571.

History of Cosmetics. 2017. Timeline of Cosmetics. www. historyofcosmetics.net/cosmetic-history/ Accessed on 14 March 2017.

Ionescu (Bordei), N., Ivopol, G.C., Neagu, M., Popescu, M. \& Meghea, A. 2015. Fatty acids and antioxidant activity in vegetable oils used in cosmetic formulations. UPB Science Bulletin Series B 77(3): 39-48.

Javed, S. \& Atta-ur-Rahman. 2014. Aloe vera gel in food, health products, and cosmetics industry. In Studies in Natural
Products Chemistry, Vol. 41, edited by Atta-ur-Rahman, Oxford, UK: Elsevier B.V. pp. 261-285.

Joshi, L.S. \& Pawar, H.A. 2015. Herbal cosmetics and cosmeceuticals: An overview. Natural Products Chemistry \& Research 3(170): 1-8.

Jung, J.Y., Kwon, H.H., Hong, J.S., Yoon, J.Y., Park, M.S., Jang, M.Y. \& Suh, D.H. 2014. Effect of dietary supplementation with omega-3 fatty acid and gamma-linolenic acid on acne vulgaris: A randomised, doubleblind, controlled trial. Acta Dermato-Venereologica 94: 521-525.

Kadam Vaishali, S., Chintale Ashwini, G., Deshmukh Kshitija, P. \& Nalwad Digambar, N. 2013. Cosmeceuticals an emerging concept: A comprehensive review. International Journal of Research in Pharmacy and Chemistry 3(2): 308-316.

Kamakshi, R. 2012. Fairness via formulations: A review of cosmetic skin-lightening ingredients. Journal of Cosmetic Science 63: 43-54.

Kasuan, N., Muhammad, Z., Yusof, Z., Rahiman, M.H.F., Taib, M.N. \& Haiyee, Z.A. 2013. Extraction of Citrus hystrix D.C. (kaffir lime) essential oil using automated steam distillation process: Analysis of volatiole compounds. Malaysian Journal of Analytical Sciences 17(3): 359-369.

Kim, M.J., Doh, H.J., Choi, M.K., Chung, S.J., Shim, C.K., Kim, D.D., Kim, J.S., Yong, C.S. \& Choi, H.G. 2008. Skin permeation enhancement of diclofenac by fatty acids. Drug Delivery 15(6): 373-379.

Kong, R., Cui, Y., Fisher, G.J., Wang, X., Chen, Y., Schneider, L.M. \& Majmudar, G. 2016. A comparative study of the effects of retinol and retinoic acid on histological, molecular, and clinical properties of human skin. Journal of Cosmetic Dermatology 15: 49-57.

Kumar, D., Rajora, G., Parkash, O., Himanshu, Antil, M. \& Kumar, V. 2016. Herbal cosmetics - A review. International Journal of Advanced Scientific Research 1(4): 36-41.

Kusumawati, I. \& Indrayanto, G. 2013. Chapter 15: Natural antioxidants in cosmetics. In Studies in Natural Products Chemistry (Vol 40), edited by Atta-ur-Rahman, F.R.S. Oxford, UK: Elsevier B.V. pp. 485-595.

Lambert, T. 2017. A Timeline of Cosmetics and Make Up. www. localhistories.org/cosmeticstime.html. Accessed on 14 March 2017.

Le Floc'h, C., Cheniti, A., Connétable, S., Piccardi, N., Vincenzi, C. \& Tosti,A. 2015. Effect of a nutritional supplement on hair loss in women. Journal of Cosmetic Dermatology 14: 76-82.

Lee, N-Y., Wong, L.P., Siti Hamidah M-S., Zuhaili, I., Mohd Azizi C.Y. \& Ida-Idayu, M. 2014. Application of rubber (Hevea brasiliensis) seeds oil extracted using supercritical carbon dioxide in cosmetics. Jurnal Teknologi 69(4): 55-59.

Ma, Y., Ma, J., Yang, T., Cheng, W., Lu, Y., Cao, Y., Wang, J. \& Feng, S. 2014. Componets, antioxidant and antibacterial activity of tomato seed oil. Food Science and Technology Research 20(1): 1-6.

Martorana, M., Arcoraci, T. \& Rizza, L. 2013. In vitro antioxidant and in vivo photoprotective effect of pistachio (Pistacia vera L., variety Bronte) seed and skin extracts. Fitoterapia 85: 41-48.

Masri, R., Ismail, R. \& Ahmad, S. 2002. Palm-based cosmetic products with roselle extract. $M P O B$ Information Series. pp. 156-160.

Matthews, I. 2007. Naturals hit mainstream. In Natural and Organics in Cosmetics: From $R$ and $D$ to the Marketplace, edited by Lawrence, B.M. USA: Allured Publishing Corporation. pp. 17-20. 
Owh, C., Chee, P.L. \& Loh, X.J. 2016. A global analysis of the personal care market. In Polymers in Personal Care Products and Cosmetics, edited by Loh, X.J. London: Royal Society of Chemistry.

Palombo, P., Fabrizi, G., Ruocco, V., Ruoccom, E., Fluhr, J., Roberts, R. \& Morganti, P. 2007. Beneficial long-term effects of combined oral/topical antioxidant treatment with the carotenoids lutein and zeaxanthin on human skin: A double-blind, placebo-controlled study. Skin Pharmacology and Physiology 20: 199-210.

Pandel, R., Poljŝak, B., Godic, A. \& Dahmane, R. 2013. Skin photoaging and the role of antioxidants in its prevention. ISRN Dermatology 2013: 1-11.

Peng, W.L., Khanafi, M.A., Setapar, S.H.M., Idham, Z., Yunus, M.A.C. \& Abbas, M.Z.A. 2014. Development of emulsification containing natural colorant from local plant (Roselle). Jurnal Teknologi (Sciences \& ngineering) 69(4): 15-17.

Personal Care Products Council. 2016. A History of Cosmetics from Ancient Times. www.cosmeticinfo.org . Accessed on 14 March 2017.

Prapun, R.,Cheetangdee,N.\& Udomrati,S. 2016.Characterization of virgin coconut oil (VCO) recovered by different techniques and fruit maturities. International Food Research Journal 23(5): 2117-2124.

Puglia, C. \& Bonina, F. 2008. In vivo spectrophotometric evaluation of skin barrier recovery after topical application of soybean phytosterols. Journal of Cosmetic Science 59: 217-224.

Quirin, K.W. 2011. Phytosterol-rich extracts and anti-aging benefits. Euro Cosmetics 19: 16-18.

Rele,A.S. \& Mohile, R.B. 2003. Effect of mineral oil, sunflower oil, and coconut oil on prevention of hair damage. Journal of Cosmetic Science 54: 175-192.

Ruszova, E., Cheel, J. \& Pavek, S. 2013. Epilobium angustifolium extract demonstrates multiple effects on dermal fibroblasts in vitro and skin photo-protection in vivo. General Physiology and Biophysics 32: 347-359.

Saba.2016. 15 Best Benefits and Uses of Beta Carotene for Skin, Hair and Health. http://www.stylecraze.com/ Accessed on 15 March 2017.

Sato, K. \& Toriyama, M. 2009. Depigmenting effect of catechins. Molecules 14: 4425-4432.

Scarmo, S., Cartmel, B., Lin, H., Leffell, D.J., Welch, E., Bhosale, P., Bernstein, P.S. \& Mayne, S.T. 2010. Significant correlations of dermal total carotenoids and dermal lycopene with their respective plasma levels in healthy adults. Archives of Biochemistry and Biophysics 504(1): 34-39.

Sevin, A., Oztas, P. \& Senen, D. 2007. Effects of polyphenols on skin damage due to ultraviolet A rays: An experimental study on rats. Journal of European Academy of Dermatology and Venereology 21: 650-656.

Shafiei, Z., Shuhairi, N.N., Yap, N.M.F.S., Sibungkil, C.A.H. \& Latip, J. 2012. Antibacterial activity of Myristica fragrans against oral pathogens. Evidence-Based Complementary and Alternative Medicine 2012: Article ID 825362.

Shinkafi, S.A. \& Ndanusa, H. 2013. Antibacterial activity of Citrus limon on Acnevulgaris (pimples). International Journal of Science Inventions Today 2(5): 397-409.

Singh, D.K., Luqman, S. \& Mathur, A.K. 2015. Lawsonia inermis L. - A commercially important primaeval dying and medicinal plant with diverse pharmacological activity: A review. Industrial Crops and Products 65: 269-286.
Soto, M.L., Falqué, E. \& Domínguez, H. 2015. Relevance of natural phenolics from grape and derivative products in formulation of cosmetics. Cosmetics 2: 259-276.

Soukoulis, S. \& Hirsch, R. 2004. The effects of a tea tree oilcontaining gel on plaque and chronic gingivitis. Australian Dental Journal 49(2): 78-83.

Sun, Y., Lin, Y., Cao, X., Xiang, L. \& Qi, J. 2014. Sterols from Mytilidae show anti-aging and neuroprotective effects via anti-oxidative activity. International Journal of Molecular Sciences 15: 21660-21673.

Srivastava, V., Dubey, S. \& Mishra, A. 2013. A review on lemon grass: Agricultural and medicinal aspect. International Research Journal of Pharmacy 4(8): 42-44.

Telang, P.S. 2013. Vitamin C in dermatology. Indian Dermatology Online Journal 4(2): 143-146.

Teo, W.L., Gan, E., Jinghan, A., Chuah, S.Y. \& Alain, K. 2015. Double blind placebo controlled trial to evaluate of the effectiveness of a dietary supplement rich in carotenoids as adjunct to topical lightening cream for the treatment of melasma: A pilot study. Pigmentary Disorders 2(164): 1-6.

Thornfeldt, C. 2005. Cosmeceuticals containing herbs: Fact, fiction, and future. Dermatologic Surgery 31(7 Pt 2): 873-880.

Uchida, R., Ishikawa, S. \& Tomoda, H. 2014. Inhibition of tyrosinase activity and melanine pigmentation by 2-hydroxytyrosol. Acta Pharmaceutica Sinica B 4(2): 141145.

Vermerris, W. \& Nicholson, R. 2006. Phenolic Compounds Biochemistry. Dordrecht, Netherlands: Springer.

Yogiraj, V., Goyal, P.K., Chauhan, C.S., Goyal, A. \& Vyas, B. 2014. Carica papaya Linn: An overview. International Journal of Herbal Medicine 2(5): 01-08.

Zillich, O.V., Schweiggert-Weisz, U., Eismer, P. \& Kerscher, M. 2015. Polyphenols as active ingredients for cosmetic products. International Journal of Cosmetic Science 37: 455-464.

Hasmida Mohd-Nasir \& Siti Hamidah Mohd-Setapar* Centre of Lipid Engineering and Applied Research (CLEAR) Ibnu Sina Institute for Scientific and Industrial Research Universiti Teknologi Malaysia 81310 UTM Johor Bahru, Johor Darul Takzim Malaysia

Siti Hamidah Mohd-Setapar*

Faculty of Chemical and Energy Engineering

Universiti Teknologi Malaysia

81310 UTM Johor Bahru, Johor Darul Takzim

Malaysia

Siti Hamidah Mohd-Setapar*

SHE Empire Sdn Bhd

No 44, Jalan Pulai Ria 2

Bandar Baru Kangkar Pulai

81300 Skudai, Johor Darul Takzim

Malaysia

*Corresponding author; email: sitihamidah@cheme.utm.my

Received: 11 July 2017

Accepted: 28 November 2017 